Original Article

Received/Accepted Dates

05.11.2021/21.12.2021

DOI: 10.52096/jsrbs.7.14.2
Journal of Social Research and Behavioral Sciences

Sosyal Araştırmalar ve Davranış Bilimleri Dergisi

ISSN:2149-178X

Volume: 7 Issue: 14 Year: 2021

\title{
Where is The Limit of Questioning More? A Study of The Proper Use of The Concept of Critical Thinking
}

PhD Student Alexandra-Niculina BABII

Alexandru Ioan Cuza University of Iași

alexandra.babii@yahoo.com

\begin{abstract}
Critical Thinking is a sum of abilities that are more and more required today in this world of disinformation. Critical Thinking even started to become a philosophy of life where people must carefully evaluate the information they encounter. However, this statement of ,think critically” has started to be used by entities who promote false theories, fake news and unsound arguments. For example, the motto of the controversed news outlet Russia Today is „Question more”. Another example is that on the social network of Instagram, the hashtag \#criticalthinking is used in posts that promote the theory of the flat earth, that promote antivaxxing movement and so on. If we are to be put in an average person's shoes, how would we know which critical thinking is the right one? How would we know who to believe? This paper's aim is to emphasize the importance of critical thinking standards and criteria and to analyse them in order to make the difference between a proper use of this statement and an abusive and alleged one.
\end{abstract}

Keywords: critical thinking, fake news, thinking standards, question more.

\section{Introduction}

The autonomy of thinking was put on different places throughout the history, but these days we feel the need of being more and more awake and more and more aware of our own thinking. In a continuous uncertainty, we look for information that can ensure us, that can guide us and that can show us the truth. In this search we meet all kinds of opinions, we encounter information which 
we try to asses, but often we do not have all the tools we need. We meet fake news at every step and many times we cannot differentiate it from good news. Different entities blame the others for delivering fake news and we do not know who to believe. We feel insecure and often we feel that the only thing we can rely on is our own mind, but this mind is not always rational, as we know. It is a period when everybody is saying that we should think critically, that we should question the information that is delivered to us, that we should have a pound of skepticism with which we analyse the world. We should always check the source of the information, we should be aware of who is talking, we should not believe everything. And in all this avalanche of information, what is the truth? Who should we believe? How many questions should we ask? This paper's trying to find some answers to these questions and present some criteria which should we use when we have the feeling that we are lost and nobody is trustful.

\section{Critical Thinking}

What is critical thinking? Critical thinking is seen as rational and reflective thinking which determines the decision of what to believe and what to do (R. Ennis, 1989). It is not about being critical about everything, but it is about applying rational criteria to everyday life. Besides rational thinking, the focus is on reflective thinking - the act of taking the time to reflect on the content on thinking and on the way we think. Fisher and Scriven see critical thinking as `skilled, active interpretation and evaluation of observations, communications, information and argumentation` (A. Fisher and M. Scriven, 1997). This definition explains in a more specific way the types of information we can evaluate having a critical mind: from the observations we have about the world, the communication we have with people to the information in the form of arguments. Argumentation is a key word for critical thinking because the ideas we present or the affirmations we make have to be based on arguments, especially even if it something important. In the same time, we have to pay attention of the arguments of the other one to see if they are valid or not, if they are strong or weak or, in other words, if they are good enough to take into consideration.

A critical thinker has a sum of abilities. Peter Facione lists six abilities such as: interpretation, analysis, evaluation, inference, explanation, self-regulation (P. Facione, 2005). Interpretation refers to the ability of understanding and express the meaning and the signification of different situations, experiences, events, beliefs, information; Analysis is about identification of inferential 
relations between concepts, descriptions, affirmations or other ways of information presentation; Evaluation is the core of critical thinking and refers to assessing the credibility of information, people, experiences but also is about the evaluation of arguments; Inference regards the identification of the required elements for drawing conclusions from a logical point of view; Explanation helps to form an overview of a situation by describing methods, procedures, by presenting additional information; Self-regulation regards the individual himself. He must apply all the criteria to his own mind, to be aware of his thinking, to search for improvements and to accept the idea that he may be wrong (P. Facione, 2005).

Critical thinking is very 'wanted' and promoted these days by different entities for which autonomous individuals are an asset, not a threat. From an economical point of view, companies are interested to have open minded employees who cand carefully asses the information during their tasks. World Economic Forum published the top ten skills that are most important for companies, skills that are wanted to be held by their employees by 2025 . Critical thinking is on the 4th place immediately after analytical thinking and innovation, active learning and learning strategies and complex problem solving (World Economic Forum, 2020).

Critical thinking became a subject taught in schools around '70s when students were in need of tools to understand the world and its political situation. The students felt that classic logic was not enough and Howard Kahane introduced the first course in Logic and Argumentation for college students (H. Kahane, 2018). Nowadays, critical thinking is studied most often in universities, but a lot of high-schools and secondary levels started to see its importance. In the same time, there is a big interest in teaching critical thinking in informal framing as trainings, courses and workshops. Many training companies have critical thinking on their list of subjects.

Summing up, critical thinking is rational, aware and reflexive thinking about the information we encounter daily. The domain of critical thinking evolved in many areas and today there are many entities who promote it focusing on the idea that people should think critically and ask many questions. Up until when?

\section{Whose weapon is critical thinking?}

We've heard that these days there is an informational war around the world where the weaponry is represented by fake news and its various forms. How can we, as individuals, fight in this war? 
Usually, the answer is concerning the developing of our own critical thinking. We often hear: 'think critically', 'question more', 'do not accept everything you hear'. How can we do that if this can be said by everyone?

The red flagged publication Russia Today has a statement on the website where it says: 'Question more'. This publication is known as being a platform of propaganda and disinformation (O. Kamm, 2021), but still it promotes the idea that people should question more and it induces that all the content of the publication is carefully written after the journalists questioned everything and thought critically. For an individual who is confused, this might be a sign of credibility.

Social Media is full of content who promotes critical thinking, but in a wrong way. Below there are some examples of Instagram posts that have in their description hashtags with words that promote critical thinking, but the message they publish is conspirational.

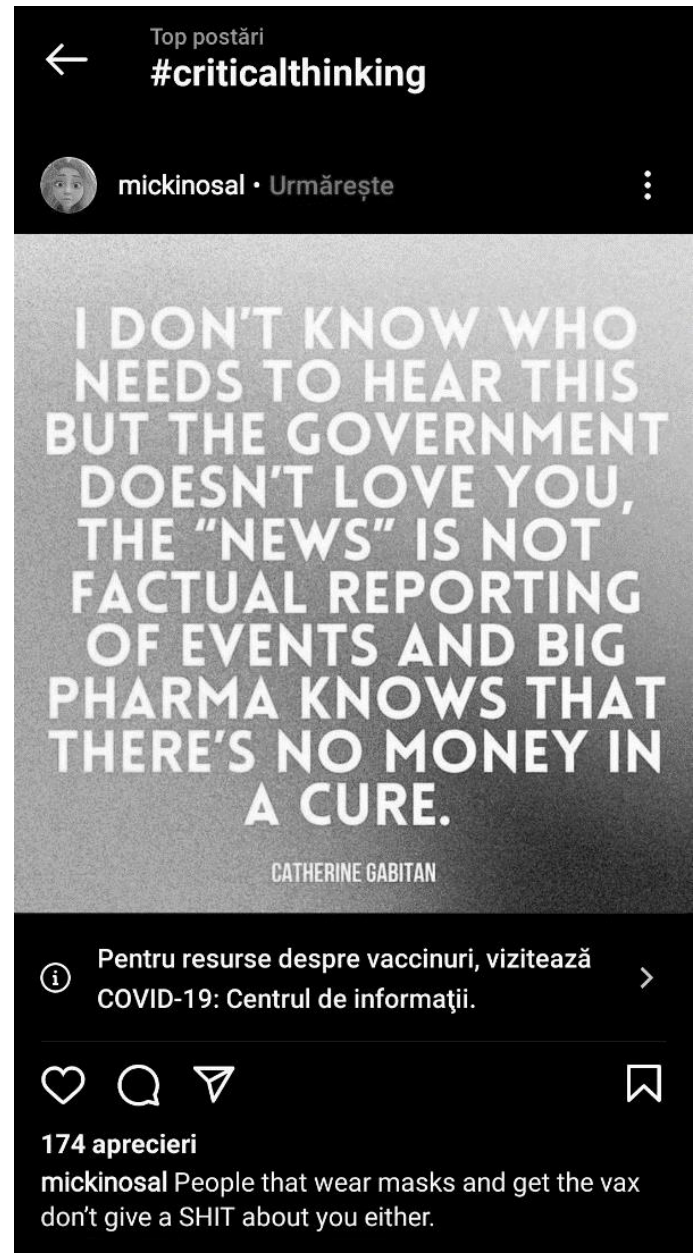

(Fig.1)
Posted @withregram•@peanut_420. \#commonsense \#DoNOTcomply \#SpreadAwareness \#screenshot \#share \#poisoning \#agenda21 \#criticalthinking \#DoYourResearch \#plandemic \#covid \#WakeUp \#UnplugFromTheMatrix \#scamdemic \#hoax \#trustyourintuition \#protectyourself \#detox \#mindcontrol \#brainwash \#sheeple \#OpenYourThirdEye \#donotcomply \#offgrid \#detoxyourmind \#makeamericafreeagain \#thinkforyourself \#justsayno \#newworldorder 
In the first example, we can see that a post that affirms the fact that the Government, the Media and the pharmaceutical companies carefully work together against the benefit of people. This is a conspirative information which has in the hashtags words like \#critical thinking, \#doyourresearch, \#detoxyourmind, \#commonsense, \#thinkforyourself. They use it as an incentive for people to think critically, but it is done in a direction of extreme skepticism and this is dangerous.

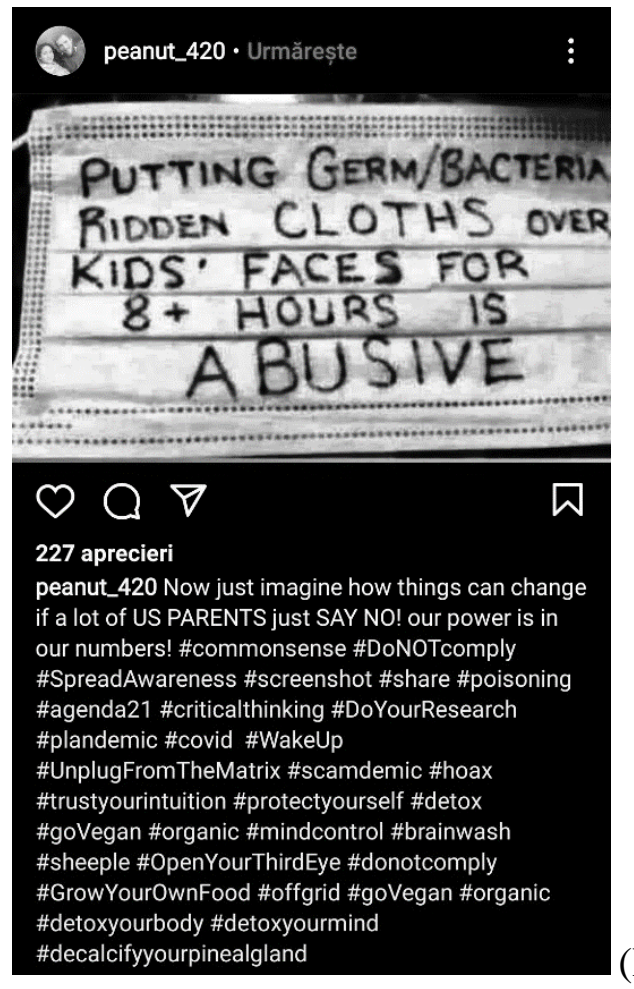

(Fig.2)

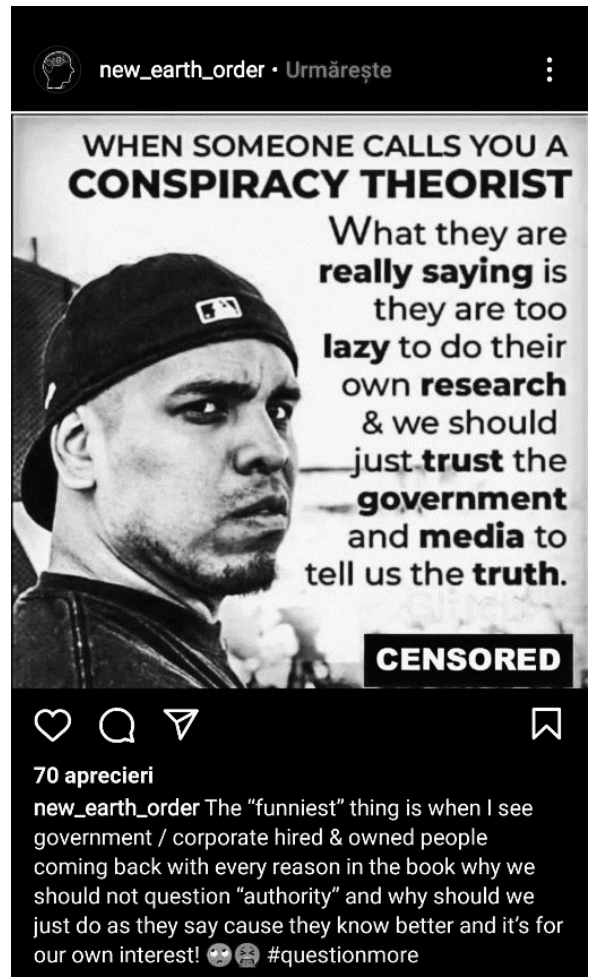

(Fig.3)

In the second example there is picture of a surgical mask saying that the mandatory law which state that children need to wear it at school is abusive because the masks are the proper place for germs and bacteria to develop. The hashtags under the post are pretty much the same: \#plandemic, \#criticalthinking, \#doyourresearch, \#protect yourself.

The third example affirms that a conspiracy theorist actually is a person that does his own research, that thinks critically, that does not believe every piece of information from the media and the government (but they believe others non-official). The hashtag that promotes it is \#questionmore. If a person receives a contradictory information for the same subject, for example anti-covid vaccination, who should he believe? If the government and media say ,think critically, choose your sources of information wisely and do your research", and in the same time different entities 
that are against vaccine say the same, what are the landmarks that should be taken into consideration for such a judgement?

\section{Standards of Critical Thinking}

Firstly, it is important to mention that even some conspiracy theories seem to be illogical and fantasies, people who believe them reason quite logical about them. Gerard Bronner affirms the fact that conspiracy theories present facts, testimonials and deductions that can be really convincing. There is a coherence in the logic of these believers. They also need proofs and arguments to strengthen their beliefs, and it is not hard to find these evidences if the persons are already decided what to believe (G. Bronner, 2016). Concerning this, a first standard that can make the difference between real critical thinking and a fallacious use of this term is the ability to assume that the person might be wrong. The doubt is the one that opens the mind's doors for research and for receiving new information. A critical thinker has to develop an awareness and evaluation of his own beliefs. Questioning his own assumptions is the essential step that can diminish the confirmation bias effect. Starting from the assumption that he might be wrong, then he gives credit to more diverse sources who can be evaluated based on objective criteria.

Another important point of view is that critical thinking is a skill that differs in the degree of applying it. The Critical thinking researcher Richard Paul states that they are two types of critical thinking: strong critical thinking and weak critical thinking. The person that has a weak critical thinking reasons quite well, applies some skills, but he does it only for his own personal purpose, only to defend his own arguments and only to fulfill his own wishes. In other words, he applies only a small part of critical thinking. A person that has a strong critical thinking is a person that applies the skills whenever is necessary, regardless his own desires. A strong critical thinker is seriously taking into consideration the other's arguments and he is critical about his own thinking (R. Paul, 1981). We can take this an answer for the examples we presented above. Even if it is an inquiry, even if there are some questions, the critical thinking applied there it is a weak one and this concept is used only in their favour.

This takes us to the core of this article. Even if we presented above the most important skills people can posses if they have a critical thinking, we believe that the dispositions are more important than the skills. From the disposition to critical thinking, we can say that a reasonable thinking can be 
born. What are these dispositions? Robert Ennis presented three main dispositions that a person must have in order for him to be a strong critical thinker: 1) A critical thinker must focus on truth values of his beliefs and search for alternatives, be well informed and consider the other's point of view; 2) A critical thinker must represent his own position in a clear and honest manner by communicating with precision, using and searching for valid arguments, and by being aware of his beliefs in a reflective manner; 3) A critical thinker must care for the other's dignity and value by listening to the other's arguments and by considering the other's feelings and level of knowledge (R. Ennis, 1996). These dispositions can foster the proper place for developing a healthy critical thinking.

Last, but not least, an important standard is to check the evaluation criteria that critical thinking is promoting. It is important to check the source of information. If it is a person, then the person has to disclose the real name in order to check his history. The source has to be an expert in the area he is giving his opinion. In the same time, this expertise has to be recognized by the majority of the community of experts and his experience has to be a relevant one (B.N. Moore and R. Parker, 2012). The critical thinker must also evaluate the beliefs that stay behind the other person's words. Beliefs are really strong and influence our lives more that we think (N. Nilsson, 2014). Succeeding in identifying the other's beliefs helps the critical thinker to understand better from which place the other persons is talking and to see in which way the other person's opinion is biased.

\section{Conclusions}

There is no doubt that critical thinking is very useful weapon to have today in this informational war, but it is important to have the proper tools to use it. Today the terms 'critical thinking', 'question more', fake news` are used by everyone regardless the truth they are promoting. This can become dangerous especially for people that are confused and insecure and do not know what to believe. This paper's aim is to encapsulate the most important standards that have to be achieved in order to apply a proper critical thinking. It is important for the person to accept the idea that he might be wrong, it is important to apply a strong critical thinking and to ensure that the three dispositions are nourished: focusing on truth values of beliefs, representing an honest position and caring for the other's dignity and value. And if a person feels lost, a return to evaluation criteria is always a good move. 


\section{References}

BOARDMAN, Frank, Nancy Cavender și Howard Kahane, (2018). Logic and Contemporary Rhetoric: The Use of Reason in Everyday Life, Cengage Learning, Wadsworth, p.137.

BRONNER, Gerard, (2016). La pensée extrême, PUF, pp.49-59

ENNIS, Robert H. (1989). „Critical Thinking and Subject Specificity: Clarification and Needed Research", Educational Researcher, 18(3), p.4.

ENNIS, Robert H., (1996). „Critical Thinking Dispositions: Their Nature and Assessability”, Informal Logic, Vol. 18, Nos. 2 \& 3, 165-182, p.166.

FACIONE, Peter, (2005). Critical Thinking: What It Is and Why It Counts, Measured Reasons LLC, Hermosa Beach, CA, pp.5-8.

FISHER, Alec and Michael Scriven, (1997). Critical Thinking. Its Definition and Assessment, Edgepress: CA, USA/Centre For Research In Critical Thinking: Norwich, UK.

https://www.weforum.org/agenda/2020/10/top-10-work-skills-of-tomorrow-how-long-it-

takes-to-learn-them/

KAMM, Oliver, 'RT's fake news and propaganda should bar it from Britain', The times, https://www.thetimes.co.uk/article/rts-fake-news-and-propaganda-should-bar-it-from-britain$705 \mathrm{vjcmml}$

MOORE, Brooke Noel and Richard Parker, (2012). Critical Thinking, a 10- a ediţie, McGraw Hill, pp.118-119.

NILSSON, Nils J. (2014). Understanding Beliefs, The MIT Press Essential Knowledge Series, p.12.

PAUL, Richard (1981). Teaching critical thinking in the" strong" sense: A focus on selfdeception, world views, and a dialectical mode of analysis. Informal Logic, 4(2), p.4. 